\title{
Dynamic Analyses of Gantry Crane Under Several Trolley and Payload Movements
}

Luigi Solazzi

Associate Professor University of Brescia Department of Mechanical and Industrial Engineering

Italy

Nenad Zrnić

Full Professor University of Belgrade Faculty of Mechanical Engineering Serbia
The aim of this research is to study the dynamic behaviour of a real gantry crane subjected to the actions induced by the trolley and payload movement. A specific numerical procedure was developed and implemented in the finite element method in order to simulate different trolley movement modes on the crane's main beam. From the results, it is clear that the crane displacement, especially the longitudinal one, is strongly dependent on the acceleration both in the starting phase and in the stopping phase to which the trolley is subjected during its movement on the crane main beam. The last part of this research simulates the sudden stop of the trolley movement and subsequent payload swinging; in this case, the length of the rope that suspend the payload to the trolley has a fundamental role in the trend and maximum longitudinal crane displacement value.

Keywords: dynamic load, load movement, dynamic behaviour, dynamic analyses, lifting equipment, crane, finite element analyses.

\section{INTRODUCTION}

Lifting equipment are machines subjected to many load conditions, especially those induced by the load movement. The dynamic effects assume a fundamental role regarding the loads acting on the structure [1-5]; in fact, these effects multiply both the payload and the dead load increasing the stress value on the crane's components. Obviously, these actions are completely different from the other loading conditions such as seismic or wind actions which are applied to the whole structure and not only to the payload [6,7]. The vertical dynamic actions, which are obtained by multiplying (with a coefficient that in general varies from 1.2 to 2 ) the nominal load or working load limit of the lifting equipment $[4,8]$, are particularly important. With these considerations, the weight of the structure plays an important role, in fact the lightening of the machine structural components implies an increase in the performance of the machine as a consequence of the fact that the inertia actions are reduced [9-11]. In gantry cranes, in addition to lifting actions, also the actions induced by trolley movement are very important. These actions generate an oscillatory movement of the load and vibrations on the structure [12]. The magnitude of the oscillations and vibrations is highly dependent on the load handling principle and especially also on the trolley movement speed [13-16]. It is obvious that the oscillation of the load must be limited in order to minimize the time required for coupling and uncoupling the payload [17,18]. For example, waiting for reduction the load oscillation before releasing the payload implies increasing the time

Received: December 2019, Accepted: February 2020

Correspondence to: Prof. Dr Eng. Luigi Solazzi,

University of Brescia, Department of Mechanical and

Industrial Engineering, Brescia, Italy

E-mail: luigi.solazzi@unibs.it

doi:10.5937/fme2002281S

(C) Faculty of Mechanical Engineering, Belgrade. All rights reserved necessary for loading and unloading a cargo-ship, which involves an increase in costs. The evaluation of the payload angle oscillation can be estimated both analytically and numerically $[19,20]$. It is possible to adopt methods based on concentrated parameters (lumped parametric system) [21-23], calculation methods that also take into account the elasticity of the structure [24], based on spectral methods [25], developed on logics of control "fuzzy" [26-28] or neural networks [29].

Other techniques are founded on making certain specific paths for payload in order to reach the final position without load oscillation [30]. The present research does not focus on the payload movement, but on the actions that the trolley translation and subsequent payload pendulum generate on the structure. These actions, are not provided in standards; however, from the finite element analyses carried out it emerges that they are very important. The present work is developed through a specific numeric procedure formulated and implemented in finite element analyses in order to simulate the trolley movement with different motion modes. The research also focuses on the phase when there is also the payload oscillation or load pendulum as a consequence, for example a sudden stop of the trolley translation, after which the payload starts swinging.

\section{NUMERICAL PROCEDURE}

The purpose of this research is the definition of a numerical procedure to be implemented in a finite element analyses (using a specific software) in order to simulate the trolley and payload movement, and it was implemented and applied to a specific and real crane.

\subsection{Crane}

The crane geometry structure, on which the innovative numerical procedure for the simulation of the trolley 
movement and payload swinging by using finite elements was implemented, is reported in the paper [23].

Specifically, and very briefly, the crane is a classic portal crane, the maximum payload is $60 \mathrm{t}$, the span is $40 \mathrm{~m}$ and the crane height is $15 \mathrm{~m}$. On one side there is a leg realized by a rectangular section, while on the other side the support of the main horizontal beam is made by two circular section legs. Finite element analyses were conducted with SolidWorks ${ }^{\circledR}$ and Autodesk Simulation ${ }^{\circledR}$ software. The finite element model is made by means of plate elements with a quadratic formulation for a total of about 10,000 elements.

At the base the crane columns were constrained with hinges. Figure 1 shows the photo of the crane used in the present research, while figure 2 shows the deformation of the crane in correspondence with the first two natural frequencies. The first value is $1.801 \mathrm{~Hz}$ while the second value is $4.788 \mathrm{~Hz}$; they are very close to those reported in [23], which were estimated by analytical method.

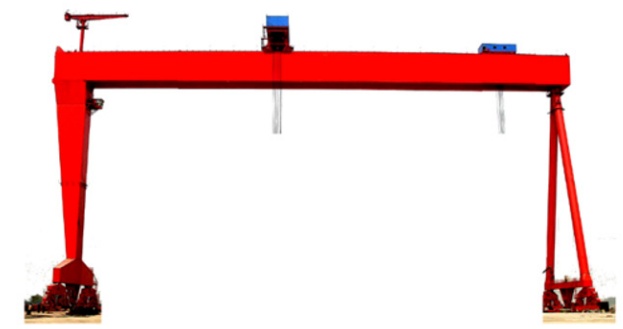

Figure 1. Crane

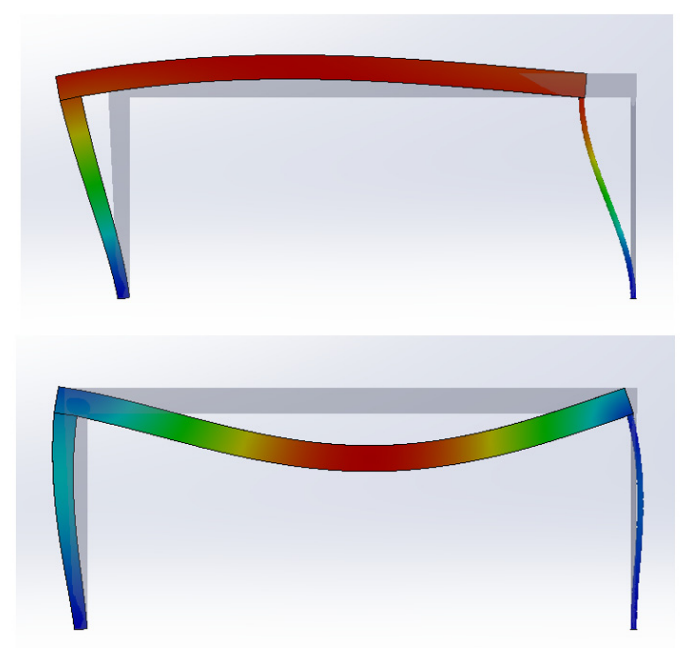

Figure 2. Main displacement in correspondence with the first two vibration modes.

\subsection{Numerical Procedure}

The definition of the calculation procedure to simulate a moving load is described in the following points. The trolley moves with a defined mode on the main crane beam. On this beam there are a series of forces whose intensity is equal to the maximum load generated by the trolley on the beam. Each force is fixed in the space but linearly variable over time. The force at point $\mathrm{n}$ grows from zero when the trolley is at point $n-1$, the value is equal to the maximum value when the trolley is at point $\mathrm{n}$ and returns to zero (in linear way) when the trolley moves to the point $\mathrm{n}+1$. This schematization is shown in figures $3,4,5$ and 6 .

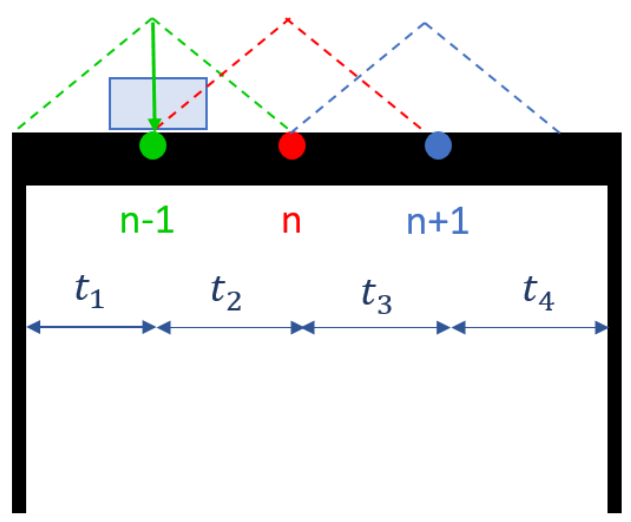

Figure 3 . The trolley is at $n-1$ point.

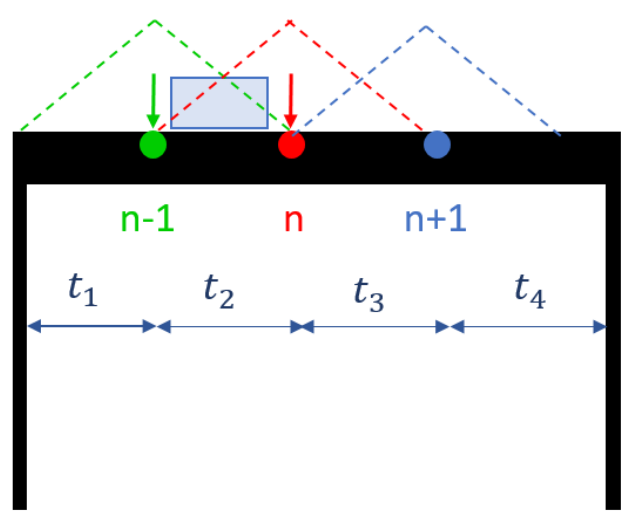

Figure 4. The trolley is at the middle point between $n-1$ and $n$.

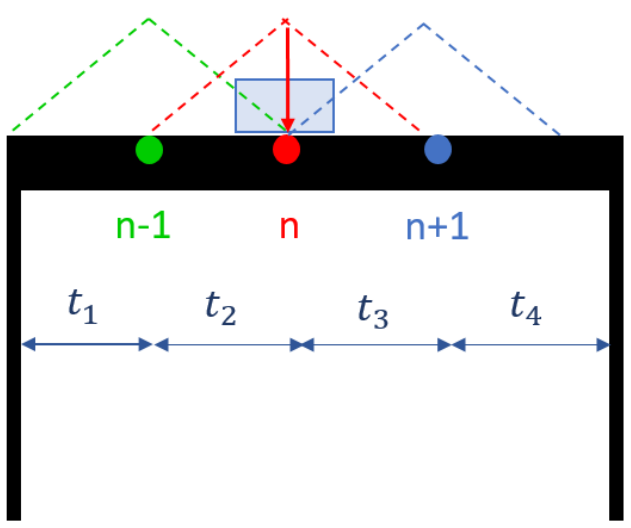

Figure 5 . The trolley is at $\mathbf{n}$ point.

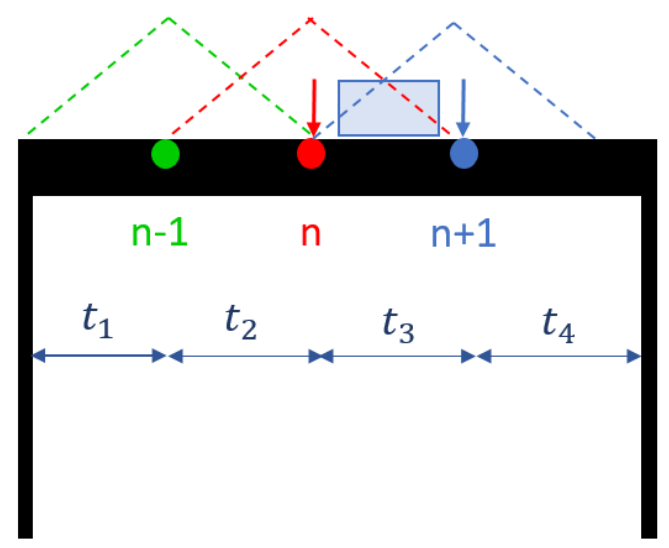

Figure 6 . The trolley is at the middle point between $\mathbf{n}$ and $n+1$. 
Obviously, this procedure presupposes that the trolley action can be schematized with a single force, otherwise as in the case, two coupled forces should be adopted in order to simulate the trolley wheels. Another important aspect to underline is the fact that the forces must be applied in correspondence with the nodes of the mesh with which the beam was discretized. In order to correctly assess the dynamic crane behaviour it is important to consider, in addition to the vertical forces, horizontal inertial forces that arise on the beam during start and stop phases of trolley movement.

\section{DIFFERENT TROLLEY MOVE MODES}

For the purpose of this research, different trolley movement modes were implemented. All these principles were characterized by a different value of the maximum acceleration imposed on the trolley. This value is the same both in the start and in the stop movement. Figure 7 refers to an acceleration equal to $0.6 \mathrm{~m} / \mathrm{s}^{\wedge} 2$ (travel time $=16.7 \mathrm{~s})$; figure 8 at $0.12 \mathrm{~m} / \mathrm{s}^{\wedge} 2($ travel time $=33.7$ $\mathrm{s}$ ), figure 9 at $3 \mathrm{~m} / \mathrm{s}^{\wedge} 2$ (travel time $=12.7 \mathrm{~s}$ ); while figure 10 refers to the implementation of a polynomial law in order to minimize the trolley acceleration (travel time $=23.1 \mathrm{~s}$ ).

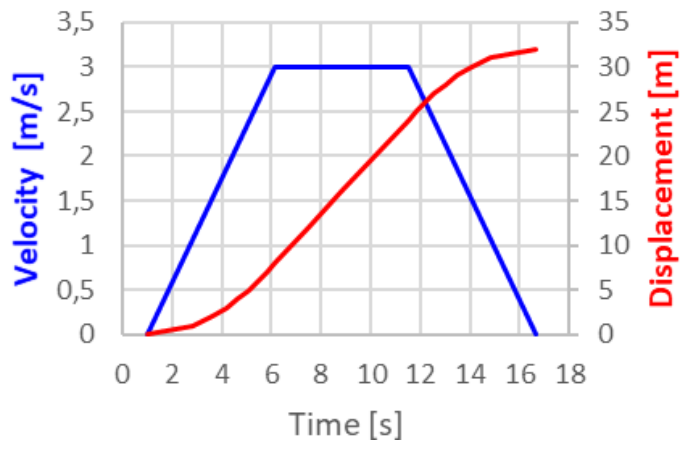

Figure 7. Trolley acceleration equal to $0.6 \mathrm{~m} / \mathrm{s}^{2}$.

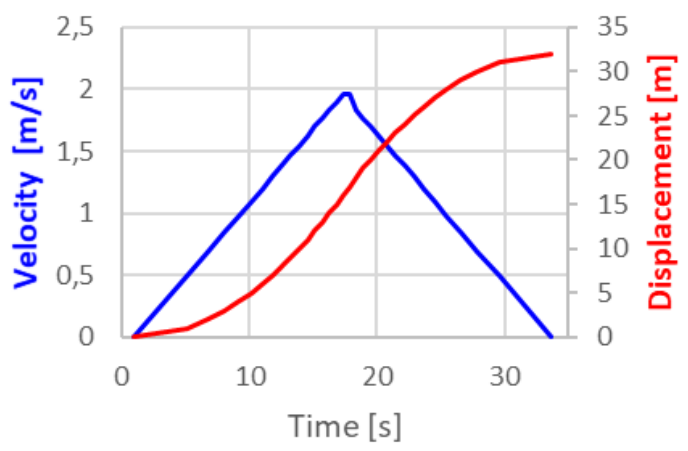

Figure 8 . Trolley acceleration equal to $0.12 \mathrm{~m} / \mathrm{s}^{2}$.

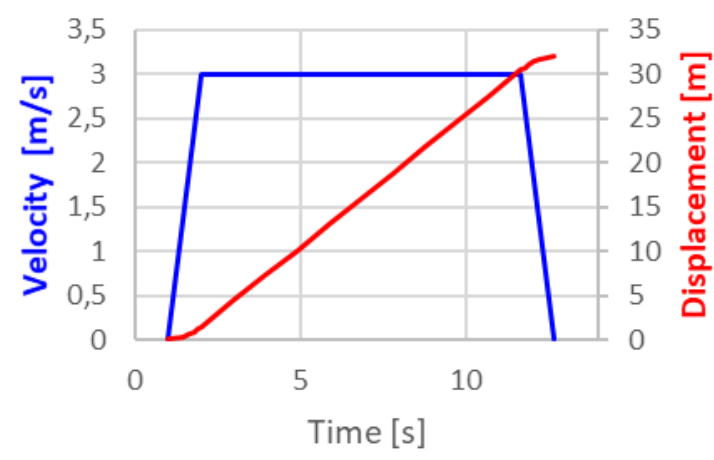

Figure 9 .3. Trolley acceleration equal to $3 \mathrm{~m} / \mathrm{s}^{2}$.

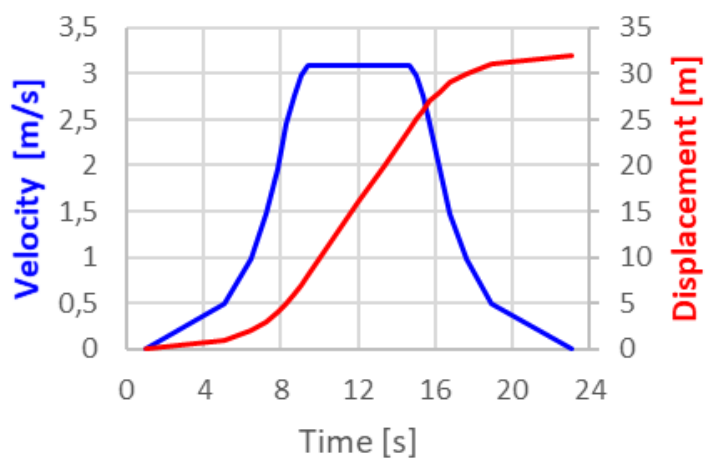

Figure 10. Trolley movement by polynomial law.

Figure 11 shows the displacement values for the midpoint or the horizontal beam in case when the trolley is moved with a mode having an acceleration equal to $0.6 \mathrm{~m} / \mathrm{s}^{\wedge} 2$ (figure 7). The maximum values are fully in agreement with what is reported in [23], where these values were determined by a discrete analytical solution.
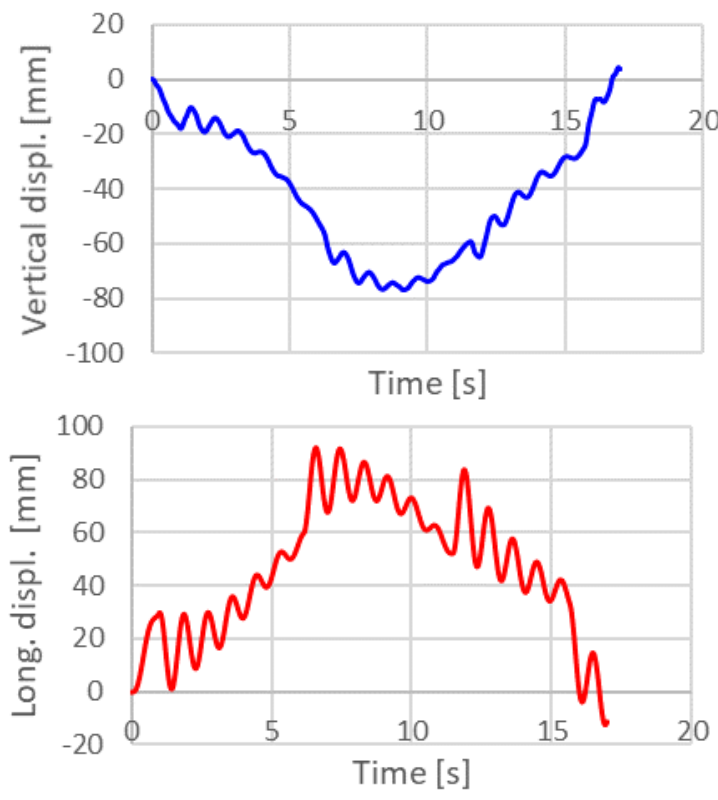

Figure 11. Displacement of the midpoint crane beam both in the vertical direction and in the longitudinal direction. The trolley was moved with an acceleration equal to 0.6 $\mathrm{m} / \mathrm{s}^{2}$.

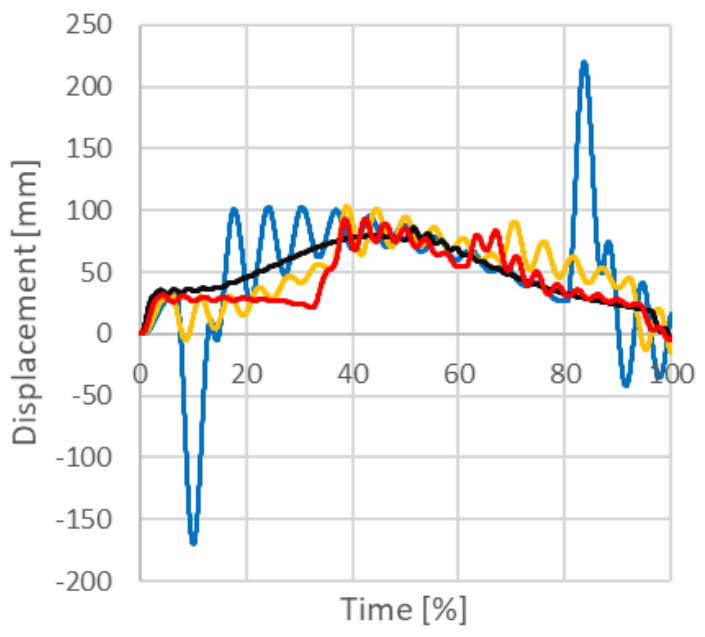

Figure 12. Longitudinal displacement for the middle beam point for different trolley moves principles. Blue acceleration $=3 \mathrm{~m} / \mathrm{s}^{2}$, yellow acceleration $=0.6 \mathrm{~m} / \mathrm{s}^{2}$, black acceleration $=0.12 \mathrm{~m} / \mathrm{s}^{2}$, red polynomial law. 
Figures 12 shows the displacements of the crane; from these graphs it is clear how the displacement both vertical and longitudinal is correlated to the maximum acceleration to which the trolley is subjected both in the start and stop phase movement. The solution of moving the trolley with a polynomial law (with the travel time value is between the trolley movement modes, one with acceleration equal to $0.12 \mathrm{~m} / \mathrm{s}^{\wedge} 2$, and with another acceleration equal to $0.6 \mathrm{~m} / \mathrm{s}^{\wedge} 2$ ) leading to the minimum displacement of the crane main beam.

The results also show that the longitudinal displacement, especially in the phase of starting and stopping movement, is greater than the vertical one.

\section{ARREST OF TROLLEY MOVEMENT}

Based on the previous elaborations, it was decided to study the phenomenon in which the trolley movement is stopped abruptly when it is at the middle point of the crane horizontal beam. This loading condition corresponds, for example, to emergency stop of the trolley movement. Braking occurs with an acceleration of $5 \mathrm{~m} / \mathrm{s}^{\wedge} 2$. This value was determined assuming that the braking torque is equal to $1000 \mathrm{Nm}$ and that it acts on the four wheels that support the trolley.

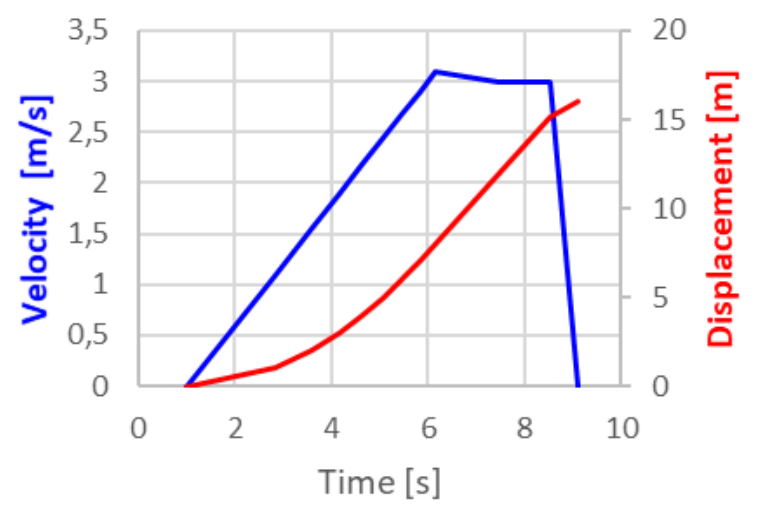

Figure 13. Trolley move mode with abrupt stop.

Figure 13 shows the motion principle applied to the trolley.

The payload distance from the trolley was simulated with the presence of ropes having different lengths as a consequence of the fact that, for example, a suitable damping coefficient is also associated with the rope presence [31,32].

\subsection{Elaboration model}

Figure 14 shows the schematization for this load configuration. In particular, the payload it was schematized like a point element. The motion of the pendulum is described by (1), while the expressions (2) and (3) show the values of tangential and centrifugal forces.

The equation that governs the motion of the pendulum can be determined in different ways, such as through the energy balance or Lagrangian method.

In any case, the angular position $\theta$ can be estimated by solving the following differential equation.

$$
\ddot{\theta}(t)+b^{*} \dot{\theta}(t)+\frac{g}{L} * \theta(t)=\frac{-\ddot{z}(t)}{L}
$$

Tangential force is:

$$
F_{t}=m^{*} L * \ddot{\theta}
$$

Centrifugal force is:

$$
F_{c}=m * L * \dot{\theta}^{2}
$$

The pendulum natural frequency is

$$
\omega=\sqrt{\frac{g}{L}-\frac{b^{2}}{4}}
$$

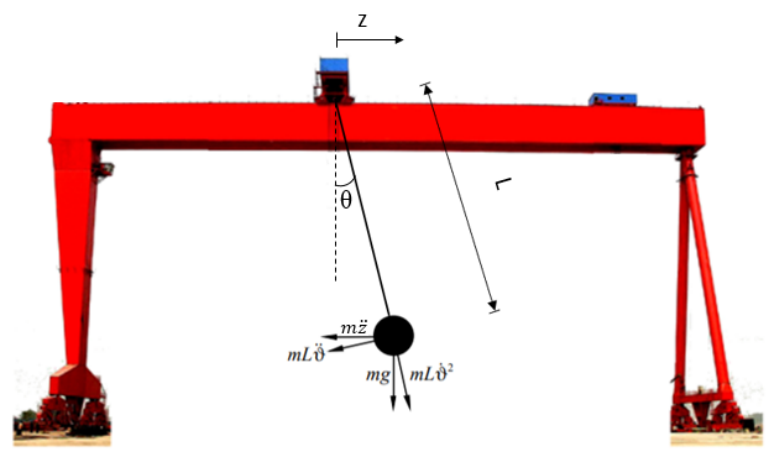

Figure 14 Payload schematization.

Once the tangential and centrifugal forces were determined as a function of the position of the $\theta$ angle and as a function of time, they were decomposed into a horizontal and a vertical component. These forces were applied on a crane beam in correspondence with the position in which the trolley was stopped, which is equal to $1 / 2$ of the length of the crane main beam.

\subsection{Rope length effect}

In order to study this effect, three different rope lengths $0.216 \mathrm{~m}, 3 \mathrm{~m}$ and $17 \mathrm{~m}$ were simulated. It was adopted that the rope length was equal to $0.216 \mathrm{~m}$ (physically not feasible. The value was chosen only for numerical analyses), in order to make the natural pendulum swing frequency equal to the crane one. In fact, as reported in equation 4), the reduction of the rope length increases the natural frequency of the payload swing; with this rope length value, the payload natural frequency is coincident of that the crane. The payload value adopted is equal to $15000 \mathrm{~kg}$.

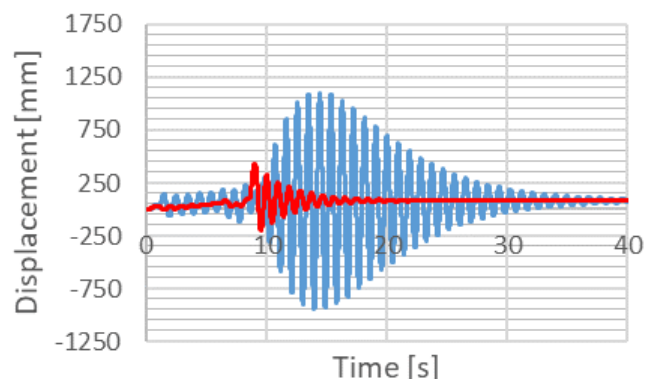

Figure 15 Longitudinal displacement, rope length $=0.216 \mathrm{~m}$, blue with swinging load, red without swinging load.

Figures 16, 17 and 18 show the displacements of the midpoint of the horizontal beam for all three rope lengths. In particular, each graph shows the displacements considering and not the payload swinging. 


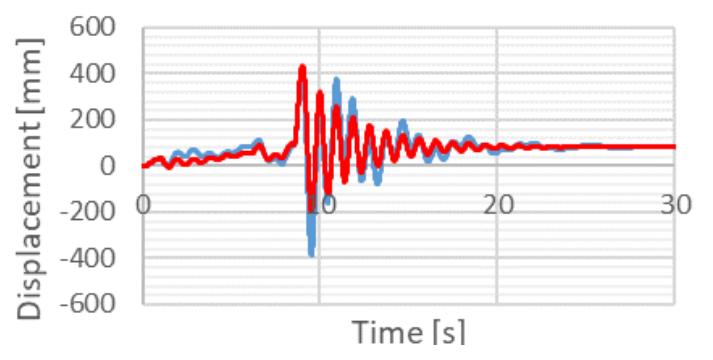

Figure 16 Longitudinal displacement, rope length $=3 \mathrm{~m}$, blue with swinging load, red without swinging load.

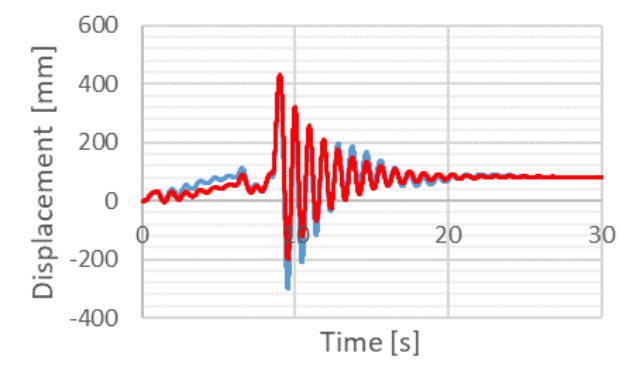

Figure 17 Longitudinal displacement, rope length $=17 \mathrm{~m}$, blue with swinging load, red without swinging load.

The graphs show how the maximum longitudinal crane displacement in the configuration in which the rope length is $3 \mathrm{~m}$ and $17 \mathrm{~m}$ is close to $400 \mathrm{~mm}$ and that the effect of the payload swinging is particularly evident on the displacement magnitude at the second peak. In the theoretical case in which the rope length is equal to $0.216 \mathrm{~m}$, the displacements diverge up to the values close to the $1 \mathrm{~m}$ (obviously considering the presence of the pendulum of the load) making this result absolutely physically unacceptable. The sudden trolley stop movement accompanied by the swinging of the payload is therefore one of the most severe load conditions to which these types of lifting equipment can be subjected.

\section{CONCLUSION}

The present work reports the main results of finite element analyses carried out on a real gantry crane with working load limit equal to $60 \mathrm{t}$ subjected to the actions induced both by the trolley movement and payload swinging. To resolve this problem, a specific numerical procedure was developed and implemented in finite element analyses. The results obtained with the trolley acceleration equal to $0.6 \mathrm{~m} / \mathrm{s}^{\wedge} 2$, are reflected in the existing literature [23]. Different trolley move modes were implemented. The results show how the longitudinal displacement is strongly dependent on the acceleration with which the trolley is moved. In the case in which a polynomial law is adopted, the longitudinal displacement value is the minimum. The work develops further as it also considers the effect of the swinging payload, which is evident when there is a sudden stop of the trolley movement. From the numerical results, it is important to highlight that the rope length that fixed the payload to the trolley is a fundamental variable that characterizes the longitudinal crane displacement. On the basis of the analyses performed, it is therefore clear that the crane longitudinal displacement is absolutely not negligible nor are the actions induced on the structure.
The future developments concern the implementation of the numerical procedure described to other lifting machines in order to deepen the study of the interaction between the structure, the movement of the trolley and the payload swinging. The research shows the importance of the actions induced on the crane by trolley movements and especially for its sudden stop. This load condition is not included in the standards for crane design and will be proposed to the standards scientific committee.

\section{REFERENCES}

[1] Yildirim, S., Esim, E.: A new approach for dynamic analysis of overhead crane systems under moving loads. Lecture Notes in Electrical Engineering, Vol. 402, 471-481, 2017.

[2] Solazzi, L., Zrnić, N.: Design of a high capacity derrick crane considering the effects induced by load application and release. Journal of Applied Engineering Science, Vol. 15 (1), 15-24, 2017.

[3] Rupar, D., Hladnik, J., Jerman, B., Yoo, SC.: Loader crane inertial forces. FME Transactions, Vol. 44, 291-297, 2016.

[4] Solazzi, L., Incerti, G., Petrogalli, C.: Estimation of the dynamic effect in the lifting operations of a boom crane. Proceeding of the 28 European Conference on Modelling and Simulation, Brescia, Italy, 309-315, 27-30 May 2014.

[5] Solazzi, L.: Experimental and analytical study on elevating working platform. Procedia Engineering, Vol. 199, 2597-2602, 2017.

[6] Solazzi, L.: Ship to shore crane subject to earthquake. Procedia Engineering, Vol. 10, 26902695, 2011.

[7] Solazzi, L., Zrnić, N.: Numerical study of wind actions applied to low profile container crane. FME Transactions, Vol. 44, 29-35, 2016.

[8] Kiviluoto, S., Eriksson, L., Koiva, H.N.: Modelling and control of vertical oscillation in overhead cranes. Proceedings of the American Control Conference, 1290-1295, 2015.

[9] Solazzi, L., Assi, A., Ceresoli, F.: Excavator arms: numerical, experimental and new concept design. Composite Structures, Vol. 11, 60-74, 2019.

[10] Solazzi, L., Scalmana, R.: New Design Concept for a Lifting Platform made of Composite Material, Applied Composite Materials, An International Journal for Science and Application of Composite Materials, Vol. 20 (4) 615,626, 2013.

[11] Solazzi, L.: Applied research for Weight Reduction of an industrial Trailer, FME Transactions, Vol. 40, $57-62,2012$

[12] Maximov, J.T., Dyunchev, V.P.: Investigation of dynamic response of "bridge girder telpher-load" crane system due to telpher motion. Coupled Systems Mechanics, Vol. 7 (4), 485-507, 2018.

[13] Korytov, M.S., Shcherbakov, V.S., Titenko, V.V.: Comparative analysis of methods of cargo vibration damping moved by overhead crane. Journal of Physics: conference series, Vol. 1050(1), 2018. 
[14] Osmanaj, S., Simnica, A.K., Limani, M., Kabashi, Q.: The sensitivity of the hoist system in crane applications from speed control methodos at induction motor. Elektrotechnik und Informationstechnik, Vol. 135 (2) 195-203, 2018.

[15] He, W.: Vertical dynamics of a single -span beam subjected to moving mass suspended payload system with variable spedds. Journal of Sound and Vibration, Vol. 418, 36-54, 2018.

[16] Gašić, V., Zrnić, N., Obradović, A., Bošnjak, S.: Consideration of moving oscillator problem in dynamic response of bridge cranes. FME Transactions, Vol. 39, 17-24, 2013.

[17]Zrnić, N., Petrović, Z., Bošnjak, S.: Automation of ship to shore container cranes: a review of state of the art. FME Transactions, Vol. 33, 111-121, 2005.

[18] Singhouse, W., Peng,K., Garcia, A., Ferri, A.: Modelling and control of crane payload lift-off and lay down operations. FME Transactions, Vol. 44, 237-248, 2016.

[19] Ohtomo, S., Murakami, T.: Experimental evaluation of estimated sway angle of payload in crane systems. IECON Proceedings Industrial Electronics Conference, 146-151, 2014.

[20] Ghafoori, E., Younesian, D.: Dynamic analysis of gantry crane subjected to a moving trolley hoisting a swinging object, Eurodyn: European Conference on Structural Dynamics, Southampton, United Kingdom, 7-9 July 2008.

[21] Bajer, C. I., Dyniewicz, B.: Numerical analysis of vibration of structures under moving inertial load, Springer, 2012

[22] Gašić, V., Zrnić, N., Milovančević, M.: Considerations of various moving load models in strucutural dynamics of large gantry cranes. FME Transactions, Vol. 41, 311-316, 2013.

[23]Zrnić, N., Gašić, V., Bošnjak, S., Đorđević, M.: Moving loads in structural dynamics of crane: bridging the gap between theoretical and practical researches. FME Transactions, Vol. 41, 291-297, 2013.

[24] Kimmerle, S-J. Gerdts, M., Herzog, R.: Optimal control of an elastic crane trolley load system a causes study for optimal control of coupled ode pde systems. Mathematical and Computer Modelling of Dynamic Systems, Vol. 24, 182-206, 2018.

[25] Wen, S.R., Wu, Z.J., Lu, N.L.: High precision solution to the moving load problem using an improved spectral element method. Acta Mechanica Sinica / Lixue Xuebao, Vol. 34(1), 68$81,2018$.

[26] Omar, H.M.: Developing anti swing fuzzy logic controller for suspended loads by genetic algorithms. International Journal of Applied
Engineering Research, Vol. 9 (16), 3455-3468, 2014.

[27] Pal A.K., Mudi, R.K.: An adaptive fuzzy controller for overhead crane. Proceedings of the 2012 IEE International Conference on Advanced Communication Control and Computing Technologies, Ramanathapuram, India, 300-304, 23-25 August 2012.

[28] Ye., Jin, W., Li, Q.: Study on overhead crane anti swing system with self-adjustable fuzzy control, Applied Mechanics and Materials, Vol. 128-129, 1050-1053, 2012.

[29] Abe, A.: Anti-sway control for overhead cranes using neutral networks. International Journal of Innovative Computing Information and Control, Vol. 7 (7B), 4251-4262, 2011.

[30] Habibi, H., O'Connor, W.: Payload motion control of rotary gantry and luffing cranes using mechanical wave concepts. Transactions of the Institute of Measurement and Control, Vol. 39 (11), 1649-1662, 2017.

[31] Kim, C.W., Hong, K.S., Lodewijks, G.: Anti-sway control of container cranes as a flexible cable systems, Proceeding of the IEE International Conference on Control Applications, Taipei, Taiwan, 1564-1569, 2-4 September 2004.

[32] Bartolini, G., Orani, N., Pisano, A., Usai, E.: Load swing damping in overhead cranes by sliding mode technique. Proceeding of the IEE International Conference on Decision and Control, Sydney, Australia, 1697-1702, 12-15 December 2000.

\section{ДИНАМИЧКА АНАЛИЗА ПОРТАЛНЕ ДИЗАЛИЦЕ ПРИ ВЕТЕМ БРОЈУ ПОКРЕТА КОЛИЦА И КОРИСНОГ ТЕРЕТА}

\section{Л. Солаци, Н. Зрнић}

Изучава се динамичко понашање реалне порталне дизалице изложене већем броју покрета колица и корисног терета. Развијен је посебан нумерички поступак који је примењен методом коначних елемената на симулацију различитих начина кретања главне греде. Резултати јасно показују да померај крана, нарочито лонгитудинални, у великој мери зависи од убрзања како у почетној тако и у фази заустављања, чему су колица изложена за време кретања главне греде крана. Последњи део рада приказује симулацију изненадног заустављања кретања колица и потоњег љуљања корисног терета; у овом случају, дужина ужета које зауставља користан терет на колицима има главну улогу у одређивању кретања и максималног лонгитудиналног помераја дизалице. 